IZA DP No. 7218

The Religious Affiliation and Anti-Semitism of Secondary School Swedish Youths: A Statistical Analysis of Survey Data from 2003 and 2009

Pieter Bevelander

Mikael Hjerm

Jenny Kiiskinen

February 2013 


\title{
The Religious Affiliation and Anti-Semitism of Secondary School Swedish Youths: A Statistical Analysis of Survey Data from 2003 and 2009
}

\author{
Pieter Bevelander \\ MIM, Malmö University \\ and IZA \\ Mikael Hjerm \\ Umeå University \\ Jenny Kiiskinen \\ MIM, Malmö University
}

\section{Discussion Paper No. 7218 \\ February 2013}

\author{
IZA \\ P.O. Box 7240 \\ 53072 Bonn \\ Germany \\ Phone: +49-228-3894-0 \\ Fax: +49-228-3894-180 \\ E-mail: iza@iza.org
}

\begin{abstract}
Any opinions expressed here are those of the author(s) and not those of IZA. Research published in this series may include views on policy, but the institute itself takes no institutional policy positions. The IZA research network is committed to the IZA Guiding Principles of Research Integrity.

The Institute for the Study of Labor (IZA) in Bonn is a local and virtual international research center and a place of communication between science, politics and business. IZA is an independent nonprofit organization supported by Deutsche Post Foundation. The center is associated with the University of Bonn and offers a stimulating research environment through its international network, workshops and conferences, data service, project support, research visits and doctoral program. IZA engages in (i) original and internationally competitive research in all fields of labor economics, (ii) development of policy concepts, and (iii) dissemination of research results and concepts to the interested public.
\end{abstract}

IZA Discussion Papers often represent preliminary work and are circulated to encourage discussion. Citation of such a paper should account for its provisional character. A revised version may be available directly from the author. 


\section{ABSTRACT \\ The Religious Affiliation and Anti-Semitism of Secondary School Swedish Youths: A Statistical Analysis of Survey Data from 2003 and 2009}

Not only in Sweden, but also in several international studies, it has been shown that a nonnegligible proportion of the European population subscribes to classical anti-Semitic notions, and that anti-Semitism is a phenomenon that is still very much present in post-1945 Europe, more so in some countries than others. Moreover, there is evidence of an increase in antiSemitic attitudes and incidents in recent decades. The latter is also depicted as being related to the Israeli-Palestinian conflict, especially the Israeli military operation Cast Lead of 20082009 which resulted in Jews being blamed for the political and military actions of the State of Israel. As prejudice is acquired in the early years of socialization, and/or is innate and fairly stable over the life cycle, examining adolescents' attitudes is vitally important because they can help us to understand what might happen in the future. Hence, the aim of this study is to study three interrelated questions: Which factors explain anti-Semitism among secondary school youths in Sweden? Is religious affiliation an important factor in explaining antiSemitism among Swedish youth? Has anti-Semitism among Swedish secondary school youths increased between 2003 and 2009? Using two unique surveys of secondary school students in Sweden for the years 2003 and 2009, we try to address the above questions. The results of our analysis show that in general anti-Semitism amongst Swedish youths is in line with the results of earlier studies. However, in contrast to the views of the general public, it has not increased during the examined period but has instead decreased. Moreover, we show that anti-Semitism has increased amongst Muslim youth.

JEL Classification: Z12, F22

Keywords: anti-Semitism, religion, attitudes

Corresponding author:

Pieter Bevelander

MIM

Malmö University

20506 Malmö

Sweden

E-mail: pieter.bevelander@mah.se 


\section{Introduction}

The Israeli military operation in the Gaza strip, named Cast Lead, conducted between $27^{\text {th }}$ December 2008 and $18^{\text {th }}$ January 2009, led to massive critique of the state of Israel in a number of European countries. Jews and Jewish institutions became targets for some of these anti-Israeli protests. In Belgium, the Netherlands, France and also Sweden, the latter being the country of examination in this article, an increase in the number of anti-Semitic hate crimes was reported to the police in the wake of Cast Lead (BR $\AA$, 2012:7). This was especially true in Malmo, the third largest city in Sweden, which has struggled, and continues to struggle with issues related to anti-Semitism and anti-Semitic incidents.

The main aim of this study is to analyze anti-Semitism among Swedish youth. More specifically, we are interested in how other religious groups behave towards Jews. The focus is on possible changes in anti-Semitic attitudes amongst Swedish secondary school students during the time period in which we witness a steep increase in hate crimes against Jewish people.

This study aims to contribute knowledge about prejudice in general and about anti-Semitism in particular. First, the general long-term trend of reduced ethnic prejudice is undisputable, whereas positive or negative changes in the short-term are still an open question (Semyonov et al. 2006; Meuleman et al. 2009). The reason for focusing on short-term changes is the suspicion that contextual changes, such as recessions, political change and the rise of the radical right in Europe, cause prejudice to fluctuate somewhat. Looking at the changes in the level of anti-Semitism is particularly interesting, because there is some evidence of an increase in anti-Semitic incidents in recent decades in most European countries (ADL 2002, 2004, 2007, 2009; EUMC 2004; FRA 2011). Figure 1, which shows the number of hate crimes reported to the police in Sweden, is in line with these studies and indicates an increasing trend over time. 
Figure 1: Number of anti-Semitic hate crimes in Sweden, 2001-2009

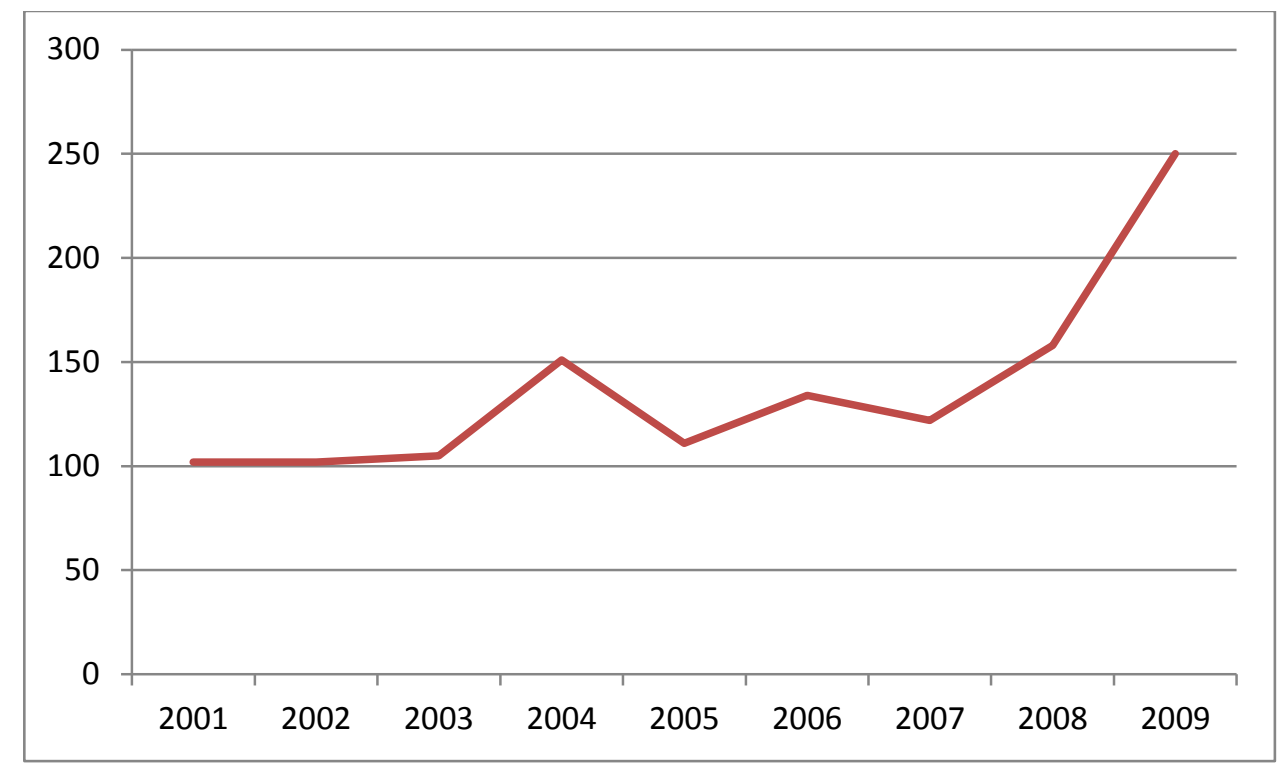

Source: The Swedish National Council for Crime Prevention (BRÅ), http://www.bra.se/bra/brott-statistik/statistik/hatbrott.html

Thus, there may be reasons to suspect that we are witnessing an increase in anti-Semitism during the examined time period.

Second, a problem with previous studies of attitudinal change is the overt focus on general changes. There are strong reasons to suggest that general trends hide changes within particular groups, i.e. groups that are particularly exposed to specific changes. For example, it is more likely that people who are more loosely attached to the labour market will be more prejudiced in times of recession, because they may be more at risk of emigration than people with a strong labour market position. Looking at anti-Semitism, it has been suggested that the Arabic or/and Muslim population identifying with the Palestinian cause was the main explanation for the increase in anti-Semitic hate crimes (Kaplan \& Small 2006; Breitman 2007; Wieviorka 2007; Baum 2009; Peace 2009; Bangstad \& Bunzl 2010; Verkuyten \& Thijs 2010; Jacobs et al. 2011). So, if attitudinal changes coincide with behavioural changes under these circumstances, possible changes may differ across groups.

Third, the relationship between individual religiosity and ethnic prejudice in general is diminishing (Hall et al. 2010) and in some countries there is now a negative relationship between individual religiosity and prejudice (Bohman \& Hjerm 2013). The problem is that 
these studies almost exclusively focus on comparisons between Christians and other people, and neglect other religious affiliations. In relation to anti-Semitism, studies from the Netherlands and Belgium show that especially Muslim youths, compared to Christian and non-religious youths, harbour negative attitudes towards Jews (Verkuyten \& Thijs 2010; Jacobs el al. 2011), although these studies fail to account for changes in attitudes.

The empirical material consists of two unique surveys conducted in 2003 and 2009 among Swedish secondary school students containing questions about attitudes towards Jews.

In the next section we focus on theory and previous research related to prejudice and antiSemitism. This is followed by a section describing the method and the data. The analysis is reported on in the following part and the article concludes with a discussion section.

\section{Theoretical point of departure and previous research}

Anti-Semitism can be defined as a lasting, latent structure of beliefs about Jews as a collective. At the individual level it manifests itself as sentiments, at the cultural level as myths, ideology and popular traditions, and at the practical level as social or legal discrimination, political mobilization against Jews and collective or governmental violence against those aiming to expel or even kill them for being Jews (Fein 1987:67). Framed within a wider perspective, anti-Semitism is a form of prejudice. As such, the same theoretical models help us to explain why certain individuals or groups of individuals hold such attitudes.

Ethnic prejudice is commonly explained by three sets of theories, or theoretical embarkation points: personality theories, social learning theories and group threat theory. Personality theories explain prejudice by referring to genetically or at least stable personality traits. For example, authoritarianism is an important factor that explains prejudice in general as well as anti-Semitism (Adorno et al. 1982 [1950]). Other personality traits, such as the big five traits, have also been shown to be of importance (Ekehammar \& Akrami 2003). Social learning theories explain prejudice by focusing on the learning process of attitudes and behaviour during early childhood and adolescence, where such attitudes are learnt from parents, peers and the surrounding society. In research about ethnic prejudice, social learning theory is often approached within the framework of symbolic theories (Kinder \& Sanders 1996; Meertens \& Pettigrew 1997; Sears et al. 1997; Henry \& Sears 2002; Sears \& Henry 2003), which assume that racism and prejudice are guided by a set of assumptions about what minority ethnic 
groups deserve and how they should act. Group threat theory (Blumer 1958; Blalock 1967) explains prejudice by focusing on the struggle for scarce resources, where the dominant group(s) perceives economic or cultural threat from the minority population, which in turn leads to prejudice. Closely related to group threat theory is the contact hypothesis (Allport 1954 (1979), which argues that increased interaction between ethnic groups can reduce ethnic prejudice.

It is important to note that although these theoretical embarkation points are by no means exclusive, they help us to understand the mechanisms behind prejudice both as a psychological process and as something that is learned and sustained over time. For example, personality theories help us to understand that people are born more or less prejudiced, but do not facilitate our understanding of which groups or individuals we are prejudiced against. Social learning theories help us to better understand the latter, whereas group threat theory helps us understand how prejudice is sustained.

Both group threat theories and symbolic theories are relevant for understanding the case studied here. Symbolic theories help us to understand an individual's psychological processes, where prejudice is the result of the divergent and non-complementary attitudes of the individual as well as how an individual learns the symbols that organize his or her world into us and them. Group threat theory provides a tool with which to understand group relations and competition between groups. More importantly, a common unification between the two theoretical strands is the emphasis on perceptions of cultural difference or ways of living. Group threat theory also emphasizes economic threats, although empirical research corroborates that perceived cultural threat is a much more prominent mechanism that drives prejudice (Dixon 2006; Hjerm and Nagayoshi 2011).

The latter is important in relation to anti-Semitism for two reasons. First, according to research by Bergmann (2008), a threat to the national group identity emerges in countries involved in the Holocaust and the atrocities committed against Jews, or in countries that see themselves as victims of the ideology of National Socialism and thereby "compete" with Jews for victim status (Bergmann 2008). This could explain the widespread negative attitudes towards Jews in countries like Germany, Austria and many of the Eastern European countries (AJC 1999; EUMC 2004; FRA 2011). But even in countries that do not belong to one of these two categories, such as Sweden, the idea of a crisis of national self-identification can be a 
valid explanation that helps us to understand anti-Semitism and anti-Semitic attitudes in post1945 Europe. Bergmann tries to answer the question about what triggers contemporary antiSemitism by unfolding what he defines as different "complexes of prejudice", that in turn are applicable to different countries due to their historical bonds and relations with Jewish communities.

Second, prejudice in Europe is commonly examined and related to immigrants - although Jews in Europe are not immigrants. Throughout Europe the Jewish population is a small and well integrated group, which means that visibility, commonly an important factor for group threat, may be of less importance. Here it is more important to think in terms of perceived group threat than realistic group threat (Bobo 1983), where classical stereotypical images of the Jewish population are widespread - images in which Jews are portrayed as an internationally interconnected group that is insinuatingly presumed to exert a far-reaching and corrosive influence on the world economy and politics (Bergmann 2008). One consequence of this line of argumentation is that Jews are not seen as belonging to the national collective, regardless of the fact that in many cases Jews have been citizens of a country for generations.

\section{Changes}

The question of ethnic prejudice in general increases or decreases depending on the time frame in focus. If we look at the long-term perspective, it is evident that ethnic prejudice and racism are decreasing. At a structural level, we have seen that apartheid, as manifested in "Jim Crow" laws ${ }^{1}$, has been abolished, and that ethnic prejudice in e.g. North America has substantially diminished over longer periods of time (e.g. Quillian 1996). When we look at the short-term perspective things become rather more complicated, because the rise and success of the radical right in a European context is often taken as evidence of increasing levels of ethnic prejudice. The latter claim is of course highly problematical, since the relationship between attitudes of prejudice and the rise of the radical right is far from simple. The picture is even hazier when we look at more recent empirical studies of change, because some scholars claim that there are either very small changes or no changes at all (Coenders \& Scheepers 1998), whereas others claim to have found some increase in ethnic prejudice (Semyonov et al. 2006).

\footnotetext{
1 "Jim Crow" laws are a set of regulations that were implemented in the United States from 1876-1965 and upheld a racial segregation between white and black Americans at the local and national level.
} 
If we turn our focus towards anti-Semitism things are a bit more straightforward, because empirical evidence shows that there has been an overall increase in such sentiments over the last decades (ADL 2002, 2004, 2007, 2009; EUMC 2004; Bergmann 2008; FRA 2011). Comparative studies that include Sweden often portray Sweden as something of an exception in this regard (EUMC 2004; FRA 2011), in that the existence of anti-Semitism is primarily seen as restricted to milieus and groups on the fringes of society. This picture is partly confirmed in two studies by the American Jewish Committee (AJC). Swedes repudiate statements of an anti-Semitic nature, including Holocaust denial (AJC 1999; 2005). Sweden is also placed at the top in relation to the other selected countries when it comes to attaching importance to Holocaust remembrance and maintaining this knowledge and remembrance over time. When it comes to factual knowledge about the Holocaust, Sweden is placed between the middle and top end of the scale in comparison with the other examined countries. $^{2}$

However, some important patterns of change are visible that are much in line with the overall development throughout Europe. Fourteen percent of Swedes (aged 15 years and over) adhere to some degree to the long-lived, ancient stereotypical notions of a worldwide Jewish conspiracy and images of Jews exerting a global influence (AJC 1999:2). Six years later, this statement is to some extent supported by 27 percent of Swedes (aged 18 years and over) (AJC 2005:7). Even though there is a change for the worse, the overall level of support is comparatively low. In a systematic comparison between this study and a study by Ring and Morgenthau (2004), the results indicate that while attitudes towards Muslims, homosexuals and refugees are becoming more tolerant, attitudes towards Jews are moving in the opposite direction. The question is, why is anti-Semitism increasing over time when more general prejudice is on the decline and displays only minor changes in more recent time periods?

\section{Religion and ethnic prejudice}

The conviction that one's own religion represents the only true faith forms the basis of individual religious loyalty (Ysseldyk et al. 2010), although it may also enforce negative reactions toward those whose perceived lack of religious enlightenment places them in an inferior moral position (Brewer 1999). Religious particularism - the perception that there is

\footnotetext{
${ }^{2}$ Both surveys were conducted after the information campaign launched by the Swedish Government in 1998. The campaign, Tell Ye Your Children, was organized by The Living History Forum, and was primarily aimed at spreading information about the Holocaust.
} 
only one true religion - has been shown to increase prejudice in groups with divergent religious beliefs (Scheepers et al. 2002). Religious fundamentalists are particularly negatively disposed toward other religious groups, which often translates into prejudice and xenophobic attitudes (Altmeyer 2003). However, in a meta-study of religiosity and prejudice, Hall et al. (2010) show that the relationship between religiosity and prejudice has been in steady decline. One criticism of this study is that it revolves around general prejudice and Christianity, whereas we have reason to believe that this development does not necessarily hold for other religious groups in relation to anti-Semitism. The main reason is that the visibility of Jews and Israel has increased lately due to external circumstances, like the Israel-Palestine conflict, and internally in relation to antagonism between Muslim and Jewish populations in specific areas in countries like Sweden. The latter has also been shown to coincide with an escalated conflict in Israel and seems to drive violence against Jews (Jacobs et al. 2011). Such an increase in visibility is likely to fuel negative attitudes. ${ }^{3}$

This aspect is of relevance in this study which focuses on attitudes towards Jews among Muslim youth in Sweden. Both historical (Breitman 2007) and contemporary manifestations of anti-Semitism are to a large extent fuelled by "the association between Jews, and the state of Israel, in the way that opinions and sentiments about the Middle East conflict influence attitudes towards Jews" (Bergmann 2008:358). This is an area of current debate that is often labelled as "new" anti-Semitism. ${ }^{4}$ A number of international studies have focused on different aspects of the relationship between anti-Semitism and the Israeli-Palestinian conflict (Kaplan \& Small 2006; Breitman 2007; Baum 2009). Jacobs et al. (2011) conclude that there was an increase in the number of reported anti-Semitic attacks in Belgium during the Israeli military operation Cast Lead in 2008-2009, but that there was no durable impact on the occurrence/presence of anti-Semitism.

\footnotetext{
${ }^{3}$ Moreover, religious-based prejudice based on Christianity is not necessarily driven by religiosity itself, whereas the perceived religious dimension in anti-Semitism is much more prevalent.

${ }^{4}$ This anti-Semitism is labelled "new" in the sense that it links hostility towards Jews to the situation in the Middle East and particularly the conflict between Israel and Palestine (Peace 2009; Bachner \& Ring 2005; Bangstad \& Bunzl 2010; Jacobs et al 2011). Timothy Peace (2009) has made a contribution to this debate and discusses whether we are facing a new kind of anti-Semitism, or if the classic anti-Semitism is going through a transformation without changing the core beliefs. Peace agrees with commentators stating that anti-Semitism has undergone a change/transformation, but disagrees with them when it comes to labelling it as a new antiSemitism. He is critical of the way that both scholars and official commentators are fusing two strands of antiSemitism together that do not necessarily have more in common than a critical approach towards the Israeli state and the way it is handling the territorial conflict in Gaza and the West Bank.
} 
Another study with an interesting approach to this is a Dutch study focusing on religious group relations among young Christian, Muslim and non-religious adolescents ${ }^{5}$ in the Netherlands (Verkuyten \& Thijs 2010). The study confirms that Muslim children in early adolescence often have negative attitudes towards Jews (and also towards Christians and nonbelievers). The results indicate a positive correlation between a higher identification with the Muslim in-group and a more negative attitude towards the Jewish out-group. This is in line with other studies that have raised awareness about the situation that is developing in Europe, in which anti-Semitic propaganda is spread via satellite television and even from some Mosques (Anti-Semitism Research 2002; Schoenfeld 2004). According to Verkuyten \& Thijs, "for some Muslims, the Jews form a "negative other" and there are indications that Dutch Muslim children reproduce the negative beliefs about Jews that exist in parts of the Muslim community" (Verkuyten \& Thijs 2010:32).

From a Swedish perspective, the thorny issue about anti-Semitism among Arab and Muslim groups was discussed in a study by Mikael Tossavainen (2003). ${ }^{6}$ A claim put forward in the report is that contemporary anti-Semitism exists and manifests itself to a great extent among groups of Arab and Muslim students in suburban schools, on Swedish Muslim websites and in the hate crimes being committed against Jews and Jewish institutions such as synagogues and cemeteries. According to Tossavainen, anti-Semitic opinions are widespread in the modern Arab and Muslim world, and that due to the political development and the growth of radical Islam, this form of anti-Semitism has intensified. Mediated by the globalization process, this form of anti-Semitism has spread to Europe through migration. Immigrants with a background in these Arab and Muslim countries mainly receive the same anti-Semitic messages and propaganda via satellite channels and different websites. Ultimately, Tossavainen describes this Arab and Muslim anti-Semitism in Europe's (and Sweden's) suburbs as a problem of a failed integration of these groups. He concludes that "[...] the segregation of immigrant neighbourhoods contributes to a situation where Arabs and Muslims in Europe remain part of the cultural discourse of their countries of origin" (Tossavainen 2005:2f).

\section{Attitudes of youth}

\footnotetext{
${ }^{5}$ Students from Years 5 and 6 in the age range 11-13. The mean age was 11 years (Verkuyten \& Thijs 2010).

${ }^{6}$ The report was part of a collaboration with the Swedish Committee against Anti-Semitism.
} 
Personality theories and learning theories assume that prejudice is acquired in the early years of socialization and/or is innate. Symbolic racism theories, as part of the more general learning theoretical concept, emphasize the importance of early socialization and the stability of these attitudes over the life cycle (Miller and Sears 1986). With regard to the older population, Miller and Sears also conclude that there is a "striking stability of major attitude" (p. 201). However, it is unclear at what exact moment in time attitudes toward various objects become stable. A problem with studies of attitudinal stability is that most longitudinal studies often either have too short a time span (e.g. Nier et al. 2000) or combine the time span problem with a focus on too young children (e.g. Doyle and Aboud 1995). However, Bachman and his colleagues (1978) show in an early study that there is an amazing attitudinal stability from adolescence to adulthood (see also Adorno et al. 1982 [1950]; Miller \& Sears 1986; Miller \& Glass 1989). Similarly, Urban and Singelmann (1997) argue that children are likely to have similar attitudes as their parents and that there is intergenerational stability in democratic orientations amongst adolescents. Other studies based on a group threat perspective (Coenders and Scheepers 1998; Kracke et al. 1998) show that changes in certain external factors, such as levels of unemployment, contribute to the formation of negative attitudes towards others. However, these studies do not refute the stability over the life cycle; they only show that factors other than family etcetera have a socializing effect on the levels of prejudice. This is not to say that ethnic prejudice or anti-Semitism cannot change over the life cycle, e.g. prejudice can be encountered with active interventions (Smith 1997; Lee 2001; Araya et al. 2002), or that external circumstances increase or decrease negative attitudes levels. In relation to the latter, it is important to note that even though ethnic prejudice may increase due to e.g. economic hardships, there is no evidence to suggest that such an increase will substantially differ across differently socialized groups. Thus, we claim that as there is strong theoretical and some empirical evidence that such attitudes are fairly stable over the life cycle, examining adolescents' attitudes is vitally important, because they can help us to understand what is likely to happen in the future. 


\section{Data and method}

The data comes from two school surveys conducted in 2003 and 2009 by the Living History Forum, Swedish Crime Prevention Board and Statistics Sweden. ${ }^{7}$ A representative sample of Swedish secondary school students was asked about their attitudes towards immigrants, immigration-specific ethnic groups as well as other things.

The response rate in the 2003 survey was $82 \%$, which corresponds to a net sample of 10,599 students in the last two years of primary school and the first to third years of secondary school. In order to make a comparison with the 2009 survey, the sample of first and third year secondary school students amounted to 4,680 students. The response rate in the 2009 survey was $77 \%$, which corresponds to a net sample of 4,674 first and third year secondary school students. The total number of respondents is 9,354 .

The dependent variable, anti-Semitism, is a constructed attitudinal index consisting of three items indicating a more positive or negative attitude towards Jews. The items are:

The Jews have too much influence in the world today (3 point scale)

There is too much talk about Nazism and the Holocaust today (3 point scale)

There is much truth in the statement that "Jews are greedy" (5 point scale).

Although the three items do not match any anti-Semitism scale perfectly, the single items and the essence of the statements are similar to Levinson and Sanford's (1944) and Selznick and Steinberg's scales (1969) of anti-Semitism and also reflect more modern adaptations of these scales (e.g. Kaplan and Small 2006; Cohen 2008). A problem with the responses is that a substantial proportion of respondents used the 'don't know' option for the first and second statements (approx. 30\%). In order to keep those respondents in the analysis, we regressed the third statement on the first two. We then collapsed the three statements and Z-scored the scale where higher values indicated stronger anti-Semitism. The index clearly taps into a more classical understanding of anti-Semitism. However, the correlation between the statement "I

\footnotetext{
${ }^{7}$ For more information about the initial questionnaire and sampling of the two surveys, see Ring \& Morgentau (2004) and Löwander (2010). The survey of 2009 was conducted in the autumn of 2009, following the Israeli military operation.
} 
dislike Jews more and more due to the politics of Israel" indicates that our measurement is far from independent of new anti-Semitism. ${ }^{8}$

In addition to the general aim of analyzing anti-Semitism among secondary school students in Sweden, the specific aim of the study is to measure the differences in anti-Semitism across ethnic groups. As we are also interested in the differences that emerge if the respondents are Muslims or not, we have chosen to use religious affiliation in order to measure this distinction. The questions are two-pronged and ask whether the respondents are religious or not and to which religion they belong if they are. We have recoded this into one variable measuring if the respondents are non-religious, Christians, Muslims, or belong to any other religion.

Survey year is the variable that is used to distinguish between the change in attitudes of secondary school students between 2003 and 2009. Since we do not observe the same individuals at two different points in time, but collapse two separate cross-sections, it shows the general attitude of secondary school students at the time of the surveys. However, in our view, this should give a good understanding of the level of anti-Semitism at those precise points in time. Moreover, in order to understand the effect of religious affiliation on antiSemitism at different points in time, we interact the variables survey year and religious affiliation.

Other control variables include all the variables that previous research has shown to be of importance when it comes to prejudice in general or that specifically relate to anti-Semitism. The gender of the students in the surveys is controlled for because earlier studies have shown that there are gender differences in attitudes towards other groups (Bevelander \& Otterbeck 2009). The educational level of the respondents cannot be controlled for directly, because all the respondents are at secondary school. However, we do control for which type of secondary school education the students participate in. We make a distinction between university preparatory programmes and other programmes (e.g. vocational programmes). Socioeconomic background is controlled for by using parental education and employment, because we know that the transmission of attitudes from parents to children and adolescents is important (Branch and Newcome 1986; Fan and Mooney 2000). Limitations in the

\footnotetext{
${ }^{8}$ Besides, an additional model including a scale variable measuring the politics of Israel showed that the effect of being Muslim had decreased.
} 
comparability across the two datasets result in a situation where we measure those variables as two dichotomies. Parental education is dichotomized as having at least one parent with university education, while parental employment is dichotomized as having at least one parent working. The importance of "urban setting" is measured as the size of the city the respondents live in divided into six categories ranging from big cities to the countryside. Immigrant background is controlled for by measuring whether the respondents were born in Sweden or not, and if they were born in Sweden whether one or both parents were born in Sweden or not. Contact is measured in relation to the subject of the attitudes in question, or in other words, whether the respondents know a Jewish person or not.

Ordinary least regression analysis is used to measure the relationships between anti-Semitism and variables in the model. We run separate regressions for 2003 and 2009 as well as a pooled dataset of 2003 and 2009.

\section{Results}

In Table 1, the results of the Means Z-score and standard deviation of anti-Semitism among Swedish secondary school youth, including all the background characteristics for the years 2003 and 2009, are presented. Given that the scale indicates the more anti-Semitic attitudes, we observe higher anti-Semitism amongst boys than girls, amongst those attending programmes other than a university preparation programme, amongst those with two unemployed parents compared to those with at least one employed parent and amongst those where both parents have no university degree compared to those where at least one parent has a university degree. The table also depicts that in 2003 anti-Semitism is more prevalent in larger cities than in other types of urban settings, whereas in 2009 larger and smaller municipalities have the highest score on our anti-Semitism scale. Individuals born outside Sweden and those born in Sweden to parents born outside Sweden have higher anti-Semitic attitudes than individuals born in Sweden whose parents were also born in Sweden and individuals born in Sweden with one parent born in Sweden. Knowing a Jewish person is correlated with lower anti-Semitism relative to not knowing a Jewish person. Non-religious individuals and those affiliated with other religions have less anti-Semitic attitudes than individuals affiliated with Christianity and Islam. Muslims clearly score the highest on our anti-Semitic scale. For individuals affiliated with Christianity and with Islam, anti-Semitism increases between 2003 and 2009. Finally, overall, very little difference in anti-Semitism is observed between the years 2003 and 2009. Thus, at least at the level of the descriptive 
information about anti-Semitism among Swedish secondary school youth, there is a broad agreement with previous research.

Table 1, Means Z-score, anti-Semitism among secondary school Swedish youth, 2003 and 2009

\begin{tabular}{lllll}
\hline & $\mathbf{2 0 0 3}$ & \multicolumn{2}{c}{$\mathbf{2 0 0 9}$} \\
& Mean & St. Dev. & Mean & St. Dev. \\
\hline Girls & $-0,256$ & 0,940 & $-0,103$ & 0,987 \\
Boys & 0,099 & 1,024 & $-0,041$ & 1,011 \\
University preparation programme & $-0,289$ & 0,943 & $-0,263$ & 0,979 \\
Other programme & 0,141 & 1,009 & 0,014 & 0,996 \\
One parent employed & $-0,122$ & 0,978 & $-0,075$ & 1,002 \\
No parent employed & 0,184 & 1,108 & $-0,029$ & 0,999 \\
One parent with university degree & $-0,186$ & 0,984 & $-0,061$ & 1,003 \\
No parent with university degree & 0,042 & 1,001 & $-0,084$ & 0,992 \\
Big cities & 0,150 & 1,127 & $-0,052$ & 1,061 \\
Other larger cities & $-0,121$ & 0,971 & $-0,111$ & 0,982 \\
Medium-sized cities & $-0,157$ & 0,962 & $-0,075$ & 0,955 \\
Large municipalities & 0,051 & 1,074 & $-0,015$ & 0,992 \\
Smaller cities & $-0,045$ & 0,920 & 0,332 & 1,138 \\
Countryside & $-0,009$ & 0,911 & $-0,012$ & 0,940 \\
Swedish born, parents born in Sweden & $-0,165$ & 0,950 & $-0,163$ & 0,938 \\
One parent born outside Sweden & $-0,087$ & 1,023 & $-0,191$ & 0,923 \\
Two parents born outside Sweden & 0,317 & 1,101 & 0,249 & 1,156 \\
Born outside Sweden & 0,378 & 1,113 & 0,402 & 1,136 \\
Knows a Jewish person & $-0,103$ & 1,060 & $-0,089$ & 0,985 \\
Does not know a Jewish person & $-0,089$ & 0,980 & $-0,061$ & 1,009 \\
Not religious & $-0,064$ & 0,992 & $-0,102$ & 0,953 \\
Other religions & $-0,171$ & 0,957 & $-0,187$ & 0,930 \\
Christian & $-0,051$ & 0,854 & 0,063 & 1,045 \\
Muslim & 0,653 & 1,146 & 0,734 & 1,223 \\
\hline Z-score & $-0,080$ & 0,999 & $-0,073$ & 0,999 \\
\hline
\end{tabular}

Where the above presented Z-scores indicate the general tendencies of individual factors on anti-Semitism, they do not show the relationship to each other, i.e. which of the factors is more or less important controlled for other general and individual characteristics of the individuals in the analyzed population. Table 2 presents a multivariate analysis in which we regress a number of individual characteristics on the probability of finding anti-Semitic attitudes among Swedish secondary school youths.

Table 2, below, consists of three separate regressions: two for the survey years 2003 and 2009 and one for the pooled data of the years 2003 and 2009. Starting with the regression for 2003, in line with the descriptive analysis discussed earlier we observe that boys to a larger degree encompass anti-Semitic attitudes in 2003 and 2009. Students attending programmes other than a university preparation programme are more anti-Semitic. Students whose parents are 
unemployed and who do not have university degrees also have stronger negative attitudes to Jews. In 2003, in relation to other types of urban settings, students living in the big cities of Stockholm, Gothenburg and Malmö have the highest levels of anti-Semitism. In 2009, students living in smaller municipalities and the countryside have the highest significant levels of anti-Semitism. In both 2003 and 2009, being born outside Sweden and being born in Sweden to parents born outside Sweden display higher levels of anti-Semitism compared to students born in Sweden and having at least one parent born in Sweden. We also see that knowing a Jewish person does not alter the grade of anti-Semitism very much in 2003 and not at all in 2009. However, as only a small number of individuals actually claim to know a Jewish person the results should be interpreted with caution.

Controlling for other variables, religious affiliation clearly affects anti-Semitism among secondary school youth in Sweden. Compared to youths who depict themselves as nonreligious, youths who are affiliated with religions other than Christianity and Islam are less anti-Semitic. Young Christians have the same level of anti-Semitism as non-religious youths in 2003, but are more anti-Semitic in 2009. Muslim secondary school youths show the highest levels of anti-Semitism in both survey years. The table also indicates that this level increases substantially between 2003 and 2009.

Finally, the pooled regression shows that controlling for other variables, the level of antiSemitism among Swedish youth has decreased, whereas at the same time the level of antiSemitism among secondary school youths depicting themselves as Muslims has increased.

Table 2: Multivariate analysis Z-score, anti-Semitism among secondary school Swedish youth, 2003 and 2009 and pooled 2003 and 2009.

\begin{tabular}{llllccc}
\hline & $\mathbf{2 0 0 3}$ & & $\mathbf{2 0 0 9}$ & \multicolumn{3}{c}{$\mathbf{2 0 0 3}$ and 2009 } \\
& Coeff. & Sig. & Coeff. & Sig. & Coeff. & Sig. \\
\hline Boys & 0,35 & $* * *$ & 0,05 & $*$ & 0,20 & $* * *$ \\
University preparation programme & $-0,40$ & $* * *$ & $-0,35$ & $* * *$ & $-0,39$ & $* * *$ \\
One parent employed & $-0,14$ & $* *$ & $-0,01$ & & $-0,086$ & $* *$ \\
One parent with university degree & $-0,14$ & $* * *$ & $-0,01$ & & $-0,08$ & $* * *$ \\
Other larger cities & $-0,24$ & $* * *$ & $-0,02$ & & $-0,10$ & $* * *$ \\
Medium-sized cities & $-0,29$ & $* * *$ & 0,04 & & $-0,10$ & $* * *$ \\
Large municipalities & $-0,21$ & $* * *$ & 0,08 & & $-0,02$ & \\
Smaller municipalities & $-0,32$ & $*$ & 0,34 & $* *$ & 0,10 & \\
Countryside & $-0,22$ & $* * *$ & 0,20 & $* * *$ & 0,04 & \\
One parent born outside Sweden & 0,07 & & $-0,04$ & & 0,02 & \\
Two parents born outside Sweden & 0,44 & $* * *$ & 0,25 & $* * *$ & 0,33 & $* * *$ \\
Born outside Sweden & 0,35 & $* * *$ & 0,31 & $* * *$ & 0,32 & $* * *$
\end{tabular}




\begin{tabular}{llllllll} 
Knows a Jewish person & $-0,07$ & $*$ & 0,00 & & $-0,02$ & \\
Other religions & $-0,06$ & $* *$ & $-0,072$ & $* *$ & $-0,07$ & $* *$ \\
Christian & $-0,07$ & & 0,125 & $*$ & $-0,04$ & \\
Muslim & 0,35 & $* * *$ & 0,705 & $* * *$ & 0,43 & $* * *$ \\
2009 & & & & & $-0,11$ & $* *$ \\
$2009 *$ Other religions & & & & & $-0,01$ & \\
$2009 *$ Christian & & & & & 0,14 & $*$ \\
$2009 *$ Muslim & & & & & 0,21 & $* *$ \\
\hline Total & 4698 & & 4413 & & 9111 & \\
\hline
\end{tabular}

Significance levels: $* * *=0,01, * *=0,05, *=0.1$.

Reference categories for dummy variables are: Girls, Vocational programme, No parent employed, No parent with university degree, Big cities, Born in Sweden with parents born in Sweden, Do not know a Jewish person, No religious affiliation and 2003.

\section{Discussion}

Returning to the research questions and theoretical considerations outlined at the beginning of the article, the results of the analysis are in line with earlier studies. Hence, boys have more anti-Semitic attitudes than girls, whereas both the educational level of the youths in question and their parental social background affect their attitudes towards Jews. The latter is in line with for example Robinson et al. (2001), who suggested that attitudes were interconnected with socialization and parental practices. Moreover, the results indicate weak support for the contact hypothesis. Knowing a Jewish person seems to be related to a more positive attitude towards Jews in 2003. However, the coefficient in 2009 is insignificant. Our understanding of this weak relationship is that very few Jews express their "Jewishness" in Sweden. The group threat theory in our analysis is verified by the categorization of the immigrant background of the individual and his/her parents. A clear significant effect of higher anti-Semitism is measured for those who migrated to Sweden and for those born in Sweden where both parents are immigrants. In our view, these results can mainly be viewed as immigrants and children of immigrants see Jews as a symbolic threat to their own position in Swedish society.

Finally, we show that anti-Semitism in general amongst Swedish youths does not increase during the period of examination. On the contrary, it decreases somewhat, which is in contradiction with the views of the general public and media reporting on hate crimes against Jews in the last decade. However, the results show that anti-Semitism increases amongst Muslim youths between 2003 and 2009.

Before we discuss these final results in more depth, some of the drawbacks of the study should be pointed out. Firstly, we do not have a real longitudinal design; we are not examining the same group of individuals in 2009 as in 2003. This means that the increase in 
anti-Semitism amongst Muslim adolescents could possibly be a result of different backgrounds, e.g. the parental country of emigration. In other words, the change is due to differences in anti-Semitic baselines across two different groups. However, it is important to note that the make-up of the Muslim group has not changed substantially over the time period, which means that we have little reason to suspect that the change we are displaying is only related to differences in composition across the groups. Moreover, we do not see any changes in the immigrant population in general (even if not controlling for denomination), which means that there is little reason to suspect large changes in coefficients over time for this important group. Secondly, we are not able to generalize across other populations because our study is geographically limited to one country. However, looking at prejudice research in general, experience has taught us that the mechanisms and explanatory circumstances are global phenomena. Thus, even though we cannot claim that the displayed increase in levels of anti-Semitism in a specific group can be generalized, we can assume that religious impact cannot be ignored - in this case, being a Muslim (see Verkuyten \& Thijs 2010:32 for the Netherlands).

In spite of these drawbacks, we conclude that our observations are important in relation to three different areas within prejudice research in general and research about anti-Semitism in particular. First, the general long-term trend of diminishing ethnic prejudice is undisputable, whereas positive or negative changes in the shorter perspective are still an open question (Semyonov, 2006; Meuleman, 2009). Our study aligns with the latter in indicating that we find small general changes in anti-Semitism. Like the mentioned studies, we have a short time span, although our results indicate that there is no trend of increasing prejudice, in this case anti-Semitism, in spite of more general trends such as the increase of political power, the visibility of radical right-wing parties, or that such attitudes are obviously related to more specific events like the increase of anti-Semitic hate crimes in the country of examination during the period.

Second, a problem with recent studies of changes in general prejudice and anti-Semitism is that they tend to focus on general changes, whereas we show that changes may occur in specific groups despite the fact that the general trend is not substantial. The latter indicates that besides focusing on possible changes in general, we should also be open to the possibility that aggregated stability in attitudes can hide diverging trends between groups. 
Third, in relation to research about religion and prejudice, we show that having a Muslim affiliation becomes increasingly important over time, especially as anti-Semitism is increasing in this group. The latter is noteworthy, because the relationship between individual religiosity and ethnic prejudice in general seems to be diminishing (Hall, et al, 2010) and some countries show a negative relationship between individual religiosity and prejudice (Bohman and Hjerm, 2013). So, the question is, why are we seeing this development? An obvious answer is related to the fundaments of group threat theory, namely that that increased visibility of the group in focus strengthens negative attitudes towards that group. More precisely, an increased media focus on Israel increases its visibility and thereby strengthens negative attitudes in the group that already demonstrates the most anti-Semitic tendencies.

To conclude, international studies and the public debate both indicate that anti-Semitism has increased. Swedish statistics on hate crimes against Jews indicate the same trend. However, even though our study is geographically limited to Sweden and uses data from two separate time periods, it shows that general patterns of prejudice, in this case against Jews, can be both stable and also change over time. It seems clear that future research into changing attitudes not only needs to focus on general trends, but should also take variation across groups into account.

\section{References}

Adorno, Theodor W, et al. (1982 [1950]) The Authoritarian Personality. New York: Norton.

Allport, Gordon (1954 (1979)) The Nature of Prejudice. Cambridge: Perseus Books.

Altmeyer, Bob (2003) "Why do Religious Fundamentalists Tend to Be Prejudiced?" International Journal for the Psychology of Religion 13 Vol.(1): pp. 17-28.

Anti-Defamation League (2002) European attitudes towards Jews, Israel and the PalestinianIsraeli conflict. Retrieved 2012-05-28 from http://www.adl.org/anti_semitism/European_Attitudes.pdf

American Jewish Committee (1999) Knowledge and Remembrance of the Holocaust in Sweden. Retrieved 2012-05-28 from http://www.ajc.org/site/apps/nlnet/content2.aspx?c=ijITI2PHKoG\&b=838459\&ct=1042063 
American Jewish Committee (2005) Thinking about the Holocaust 60 Years Later. Retrieved 2012-05-28 from

http://www.ajc.org/site/apps/nl/content3.asp?c=ijITI2PHKoG\&b=846741\&ct=1025513

Anti-Defamation League (2004) Attitudes toward Jews, Israel and the Palestinian-Israeli conflict in ten European Countries. Retrieved 2012-05-28 from

http://www.adl.org/anti_semitism/european_attitudes_april_2004.pdf

Anti-Defamation League (2007) Standing up to Anti-Semitism and Hate. Around the Globe.

In America. In your community. Retrieved 2012-05-28 from

http://www.adl.org/annual_report/Annual_Report_2007.pdf2007

Anti-Defamation League (2009) Attitudes toward Jews in seven European Countries.

Retrieved 2012-05-28 from

http://www.adl.org/Public\%20ADL\%20Anti-

Semitism\%20Presentation\%20February\%202009\%20_3_pdf

Anti-Semitism Research (2002) Antisemitism. Incidents in the Netherlands and Provisional Report from 2002. Amsterdam: Centrum Informatie in Documentatie Israel.

Araya, Tadesse, et al. (2002) "Reducing Prejudice Through Priming of Control-Related Words". Experimental Psychology 49 Vol.(3): pp. 222-227.

Bachman, Jerald G, O’Malley, Patrick M and Johnston, Jerome (1978) Youth in Transition. Vol. 6 : Adolescence to Adulthood-Change and Stability in the Lives of Young Men. Ann Arbor Mi: Institute for Social Research, University of Michigan.

Bachner, Henrik \& Ring, Jonas (2005) Antisemitiska attityder och föreställningar i Sverige. Forum för levande historia och Brottsförebyggande Rådet. Stockholm

Bangstad, Sindre \& Bunzl, Matti (2010) "Anthropologists are talking about Islamophobia and Anti-Semitism in the New Europe”. Ethnos: Journal of Anthropology 75:2: pp. 213-228.

Baum Steven ( 2009) "Christian and Muslim Anti-Semitic Beliefs". Journal of Contemporary Religion Vol 24. No 2: pp. 137-156.

Bergmann Werner (2008) "Anti-Semitic Attittudes in Europe: A comparative perspective" Journal of Social Issues Vol 64. No 2, pp. 343-362.

Bevelander Pieter \& Otterbeck Jonas (2009) "Young people's attitudes towards Muslims in Sweden”. Ethnic and Racial Studies 33:3: pp. 404-425.

Blalock, Hubert M. (1967) Towards a Theory of Minority Group Relations. New York: Wiley.

Blumer, Herbert (1958) "Race Prejudice as a Sense of Group Position". Pacific Sociological Review 1 Vol.(1): pp. 3-7. 
Bobo, Lawrence (1983) "Whites' Opposition to Busing: Symbolic Racism or Realistic Group Conflict”. Journal of Personality and Social Psychology 45 Vol.(6): pp. 1196-1210.

Bohman, Andrea and Hjerm, Mikael (2013) "How the religious context affects the relationship between religiosity and attitudes toward immigration". International Journal of Comparative Sociology Forthcoming. Vol.: pp.

Branch, Curtis W. and Newcome, Nora (1986) "Racial Attitude Development among Young Black Children as a Function of Parental Attitudes: A Longitudinal and Cross-Sectional Study". Child Development 57 Vol.(3): pp. 712-721.

Breitman Richard (2007) "Muslim Anti-Semitism: Historical Background". Current Psychology Vol 26 Issue 3-4: pp. 213-222.

Brewer, Marilynn B. (1999) "The Psychology of Prejudice: Ingroup Love or Outgroup Hate?" Journal of Social Issues 55 Vol.(3): pp. 429-444.

BRÅ 2012:7, Hatbrott 2011, Statistik över polisanmälningar med identifierade hatbrottsmotiv.

BRÅ, http://www.bra.se/bra/brott--statistik/statistik/hatbrott.html

Coenders, Marcel and Scheepers, Peer (1998) "Support for Ethnic Discrimination in the Netherlands 1979-1993”. European Sociological Review 14 Vol.: pp. 405-422.

Cohen, Florette (2008) The New Anti-Semitism Israel Model: Empirical Tests. Ann Arbor: UMI.

Dixon, Jeffrey C (2006) "The Ties That Bind and Those That Don't. Towards Reconciling Group Threat and Contact Theories of Prejudice”. Social Forces 84 Vol.(4): pp. 2179-2204.

Doyle, AB and Aboud, FE (1995) “A Longitudinal Study of White Children's Racial Prejuduces as a Social-Cognitive Development". Merrill-Palmer Quarterly Journal of development Psychology 41 Vol.(2): pp. 209-228.

Ekehammar, Bo and Akrami, Nazar (2003) "The Relation Between Personality and Prejudice. A Variable- and Person-Centered Approach". European Journal of Personality 17 Vol.(6): pp. 449-464.

European Monitoring Centre on Racism and Xenophobia (2004) Manifestations of Antisemitism in the EU 2002-2003. Retrieved 2012-05-28 from http://fra.europa.eu/sites/default/files/fra_uploads/184-AS-Main-report.pdf

European Union Agency for Fundamental Right (2011) Antisemitism. Summary overview of the situation in the European Union 2001-2010. http://fra.europa.eu/sites/default/files/fra_uploads/184-AS-Main-report.pdf

Fan, Pi-Ling and Mooney, Margaret Marini (2000) "Influences on Gender-Role Attitudes during the Transition to Adulthood". Social Science Research Vol. 29: pp. 258-283. 
Fein Helen (1987) "Dimensions of Antisemitism: Attitudes, Collective Accusations and Actions", in Fein (ed) The Persisting Question. Sociological Perspectives and Social Contexts of Modern Antisemitism. Cureent Research on Antisemitism, Vol 1, Berlin/New York: Walter de Gruyter.

Hall, Deborah L., Matz, David C. and Wood, Wendy (2010) "Why Don't We Practice what We Preach? A Meta-Analytic Review of Religious Racism". Personality and Psychology Review 14 Vol.(1): pp. 126-139.

Henry, P. J. and Sears, David O (2002) "The Symbolic Racism 2000 Scale". Political Psychology 23 Vol.(2): pp. 253-283.

Hjerm, Mikael and Nagayoshi, Kikuko (2011) "The composition of the minority population as a threat: Can real economic and cultural threats explain xenophobia?" International Sociology 26 Vol.: pp. 1-29.

Jacobs Dirk, Veny Yoann, Callier Louise, Herman Barbara (2011) "The Impact of the Conflict in Gaza on anti-Semitism in Belgium". Patterns of Prejudice, 45:4: pp. 341-360.

Kaplan, Edward H. and Small, Charles A. (2006) "Anti-Israel Sentiment Predicts AntiSemitism in Europe". The Journal of Conflict Resolution 50 Vol.(4): pp. 548-561.

Kinder, Donald R and Sanders, L (1996) Divided by Color: Racial Politics and Democratic Ideals. Chicago: University of Chicago Press.

Kracke, Barbel, et al. (1998) Adolescents, Families, and German Unification: The Impact of Social Change on Antiforeigner and Antidemocratic Attitudes. Adolescents, Cultures and Conflicts: Growing up in Contemporary Europe. J.-E. Nurmi. New York: Garland: pp. 149170.

Lee, Don (2001) "The Normal School and Some of Its Abnormalities: Community Influences on Anti-Racist Multicultural Education Developments". Race, Ethnicity and Education 4 Vol.(1): pp. 63-82.

Levinson, Daniel J. and Sanford, R. Nevitt (1944) "A Scale for the Measurement of AntiSemitism". The Journal of Psychology 17 Vol.(2): pp. 339-370.

Löwander Birgitta (2010) Den mångtydiga intoleransen. En studie av gymnasieungdomars attityder läsåret 2009/2010. Forum för levande historia. Stockholm.

Meertens, Roel W and Pettigrew, Thomas F (1997) "Is Subtle Prejudice really Prejudice?" Public Opinion Quarterly 61 Vol.(1): pp. 54-71.

Meuleman, Bart, Davidov, Eldad and Billiet, Jaak (2009) "Changing attitudes toward immigration in Europe, 2002-2007: A dynamic group conflict theory approach". Social Science Research 38 Vol.(2): pp. 352-365.

Miller, Richard B and Glass, Jennifer (1989) "Parent-child Attitude Similarity Across the Life Course". Journal of Marriage and the Family 51 Vol.: pp. 991-997. 
Miller, Steven D and Sears, David O (1986) "Stability and Change in Social Tolerance: A test of the Persistence Hypothesis". American Journal of Political Science 30 Vol.: pp. 214-236.

Nier, J A, Mottola, G R and Gaertner, S L (2000 ) "The O.J Simpson criminal Verdict as a Racially Symbolic Event. A Longitudinl Analysis of Racial Attitude Change". Personality and Social Psychology Bulletin 26 Vol.(4): pp. 507-516.

Peace Timothy (2009) 'Un antisémitisme nouveau? The debate about a 'new antisemitism' in France”. Patterns of Prejudice, 43:2: pp. 103-121.

Quillian, Lincoln (1996) "Group Threat and Regional Change in Attitudes Toward AfricanAmericans”. American Journal of Sociology 102 Vol.(3): pp. 816-860.

Ring Jonas \& Morgenthau Scarlett (2004) Intolerans. Antisemitiska, homofobiska, islamofobiska och invandringsfientliga tendenser bland unga. Forum för levande historia och Brottsförebyggande Rådet. Stockholm.

Robinson, J., Wittenberg, R. and Sanson A. (2001) "The socialisation of tolerance", in Augoustinos, M. (ed.), Understanding Prejudice, Racism, and Social Conflict, London: Sage.

Scheepers, Peer, Gijsberts, Mérove and Hello, Evelyn (2002) "Religiosity and prejudice against ethnic minorities in Europe: Cross-national tests on a controversial relationship". Review of Religious Research 43 Vol.(3): pp. 242-265.

Schoenfeld, Gabriel (2004) The Return of Anti-Semitism. San Francisco: Encounter Books.

Sears, David O and Henry, P. J. (2003) "The Origins of Symbolic Racism". Journal of Personality and Social Psychology 85 Vol.(2): pp. 259-275.

Sears, David O, et al. (1997) "Is it Really Racism? The Prigins of White Americans' Opposition to Race Targeted Policies”. Public Opinion Quarterly 61 Vol.(1): pp. 16-53.

Selznick, G. J. and Steinberg, S. (1969) The Tenacity of Prejudice. New York: Harper and Row.

Semyonov, Moshe, Raijman, Rebeca and Gorodzeisky, Anastasia (2006) "The Rise of AntiForeigner Sentiment in European Societies, 1998-2000." American Sociological Review 71 Vol.(June): pp. 426-449.

Smith, T (1997) "Recognising Difference: the Romani "Gypsy" Child Socialisation and Education Process”. British Journal of Education 18 Vol.(2): pp. 243-256.

Tossavainen Mikael (2003) Det förnekade hatet. Antisemitism bland araber och muslimer $i$ Sverige. Svenska kommittén mot Antisemitism.

Tossavainen Mikael (2005) "Arab and Muslim Anti-Semitism in Sweden”. Jewish Political Studies Review, 17:3-4 
Urban, Dieter and Singelmann, Joachim (1997) "Politische Wertorientierung bei Ostdeutschen Jugendlichen. Politische Sozialisation als Autoregressiver Prozess". Politische Vierteljahresschrift 38 Vol.: pp. 5-26.

Verkuyten Maykel \& Thijs Jochem (2010) "Religious Group Relations Among Christian, Mulism and Nonreligious Early Adolescents in the Netherlands". The Journal of Early Adolescence, Vol 30, No 1, 27-49.

Wieviorka Michel \& Bataille Phillippe (2007) The Lure of Anti-Semitism: Hatred of Jews in Present-Day France. X:Brill

Ysseldyk, Renate, Matheson, Kimberly and Anisman, Hymie (2010) "Religiosity as Identity: Toward an Understanding of Religion From a Social Identity Perspective". Personal Social Psychology Bulletin 14 Vol.(1): pp. 60-71. 